\title{
Application of an international standard pattern for financial and economical evaluation of the tourism services projects (case study Rijab- Dalahou City- Kermanshah Province)
}

\author{
Alireza Mahmoudi ${ }^{*}$ and Masoud Mahdavi \\ Department of Geography, Science and Research Branch, Islamic Azad University, Tehran, Iran. \\ alireza.mahmoudi25@yahoo.com
}

\begin{abstract}
United Nations Industrial Development Organization (UNIDO) with designing and developing of the first version of Comfar software, an international economical and financial evaluation of standard model for assessing production and services plans and projects, and selecting optimal use of investment was established for Rijab area of Dalahou district in Iran. The software receives financial and economic data, analyzes them and calculates their economic levels and the possibility of the project conducting. Rijab area, in terms of its geographical location with unique climatic conditions, cultural buildings and monuments, offers itself as a great tourist attraction especially in the West of Country. Developing the region for tourism excellence is one of the objectives of the comprehensive development plan. Therefore, attention to tourism especially rural tourism in this region is essential. The requisite development strongly considers the residence construction in planning of tourism. Hotels are the first local accommodation that should be built with attractive prospects. For this, a financial and economic justification model has to be developed. In this paper, for making application of this universal model, first by using the library and field study methods, the tourist attractiveness of the region is identified. Then, according to the statistics of tourists' inflow to the region, the correct estimation of the hotel is obtained. Afterwards, necessary data for Comfar software such as investment size, location, funding, taxes, design revenues and costs and other information needed to construct a four-star hotel in the area are prepared and installed in two Comfar and Excel software. Finally, financial and economic indexes of the design are analyzed and evaluated for justification.
\end{abstract}

Keywords: Tourism, rural development, sustainable development, economic indexes, hospitality industry, Iran

\section{Introduction}

When different ideas were proposed for investment and selection, the investors were seeking for different solutions to make the best decision. But existence of abundant parameters makes the computations so complicated by which decision maker didn't have necessary confidence in their results. On the other hand, different attitudes towards a special issue caused that the same results won't be obtained. In other words, about a plan, some computations make the plan look economical and some others refused it. Thus, standardization of definitions and computations becomes important to overcome the problem. But the main problem i.e. complexity of computational operations has been yet remained. For solving this problem, a committee was formed in United Nations Industrial Development Organization for simultaneous standardizing and computerizing of economic evaluation of plans and finally Comfar program was prepared and supplied in market.

Comfar (computer model for feasibility analysis and reporting) was prepared and codified by

Edu. Sust. Devpt.

CIndian Society for Education and Environment (iSee) economic evaluation unit of UNIDO (United Nations Industrial Development Organization) in New York in 1979. In preparing this computer program, the experiences of more than 30 economic evaluation committees of different countries have been used and supplied to the market for the first time in 1983. Fig. 1 shows a sample window of Comfar software's input. The cost of preparation of this program amounts to 1.5 Million
Fig. 1. Window of Comfar software's input (www.unido.org/comfar)

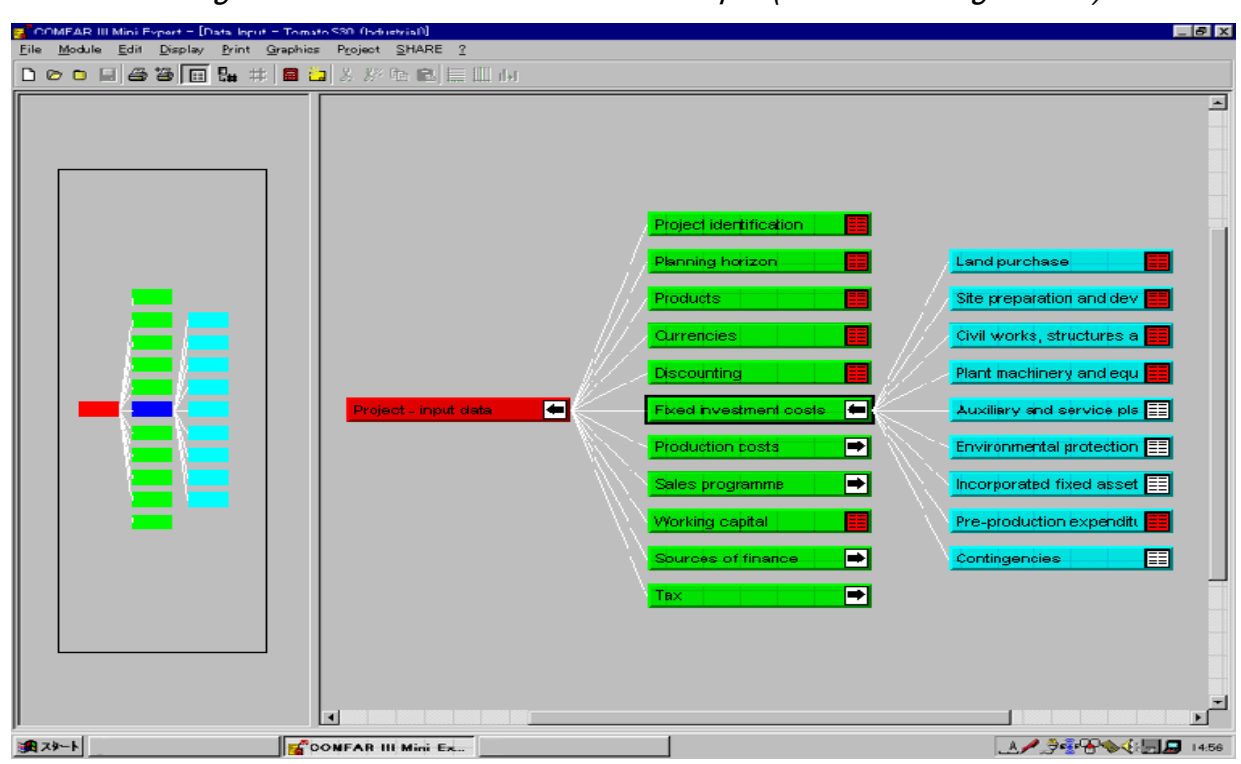

"Planning for rural tourism in Iran" http://www.indjst.org
A.Mahmoudi \& M.Mahdavi Indian J.Sci.Technol. 
dollars and now more than 0.5 Million versions are in operation all over the world and in 15 languages. Also, more than 140 countries of the world use this software for evaluating manufacturing and service plans and projects and selection of optimal alternatives for investment (www.unido.org/comfar). This software is a valuable tool for analyzing investment projects and was officially introduced in Iran in 2003. This program has this capability to receive financial and economic raw data and analyze them based on necessary instructions and illustrate the information in the Table and graph form and finally complete the rate of being economical and possibility of performing projects (UNIDO, 2008).

Table 1. Number of tourists of Rijab region in 2009 with separation of goals of

\begin{tabular}{|c|c|c|c|c|c|c|}
\hline Goal of trip & Business & Pilgrim & $\begin{array}{c}\text { Visiting } \\
\text { historical } \\
\text { places }\end{array}$ & $\begin{array}{c}\text { Visiting } \\
\text { natural } \\
\text { places }\end{array}$ & $\begin{array}{c}\text { Cultural } \\
\& \text { art } \\
\text { visiting }\end{array}$ & Total \\
\hline $\begin{array}{c}\text { No: of } \\
\text { visitors }\end{array}$ & 948 & 165,209 & 128,626 & $\begin{array}{c}147,45 \\
1\end{array}$ & 5331 & 447,565 \\
\hline Partial ratio & $15 \%$ & $6 \%$ & $3 \%$ & $4 \%$ & $2 \%$ & - \\
\hline Total users & 142 & 9,913 & 3,859 & 5,898 & 107 & 19,918 \\
\hline
\end{tabular}

Table 2. Demand of tourists to 4 star hotel of Rijab

\begin{tabular}{|c|c|c|c|c|c|}
\hline Year & $\begin{array}{c}\text { Prediction of } \\
\text { number of } \\
\text { passengers }\end{array}$ & $\begin{array}{c}\text { Average } \\
\text { time of } \\
\text { guests' stay }\end{array}$ & $\begin{array}{c}\text { Number of } \\
\text { nights of } \\
\text { guests' stay }\end{array}$ & $\begin{array}{c}\text { Number of } \\
\text { occupied } \\
\text { rooms }\end{array}$ & $\begin{array}{c}\text { Occupation } \\
\% \text { of room }\end{array}$ \\
\hline 2013 & 19,918 & 2,43 & 48,585 & 11,717 & $69,7 \%$ \\
\hline 2014 & 20,390 & 2,45 & 50,000 & 11,994 & $71,4 \%$ \\
\hline 2015 & 20,898 & 2,46 & 51,526 & 12,293 & $73,2 \%$ \\
\hline 2016 & 21,296 & 2,47 & 52,718 & 12,527 & $74,6 \%$ \\
\hline 2017 & 21,941 & 2,49 & 54,654 & 12,906 & $76,8 \%$ \\
\hline 2018 & 22,518 & 2,50 & 56,385 & 13,246 & $78,8 \%$ \\
\hline 2019 & 23,163 & 2,51 & 58,321 & 13,625 & $81,1 \%$ \\
\hline 2020 & 23,399 & 2,52 & 59,028 & 13,764 & $81,9 \%$ \\
\hline 2021 & 23,598 & 2,52 & 59,624 & 13,881 & $82,6 \%$ \\
\hline 2022 & 24,047 & 2,53 & 60,973 & 14,146 & $84,2 \%$ \\
\hline 2023 & 24,212 & 2,53 & 61,467 & 14,242 & $84,8 \%$ \\
\hline 2024 & 24,249 & 2,53 & 61,578 & 14,264 & $84,9 \%$ \\
\hline $\begin{array}{c}\text { Average } \\
\text { growth \% }\end{array}$ & $2 \%$ & $0 \%$ & $2 \%$ & $2 \%$ & $2 \%$ \\
\hline
\end{tabular}

For estimating the percent of occupation of supposed 4 star hotel plan of Rijab, it's firstly necessary that enough information about number of passengers to the hotels of Kermanshah with domestic and foreign separation and also stay average of the guests need to be obtained. Based on the statistics of the past years during 1998 to 2009 , the number of passengers to the hotels of Kermanshah has been increased from 85,683 to 250,302 and the average stay of domestic and foreign tourists has been 2 and 3 days, respectively. Also, based on the statistics of year of 2006 , only one 4 star hotel was available in center of province. The number of moved passengers has been 18,002,755 of which 14,594,657 and 3,408,098 have traveled inside and outside the province, respectively (Geography book of Kermanshah, 2006).
Vol. 4 No. 6 (June 2011)

ISSN: 0974- 6846

In order to make an accurate estimate of the statistics of 2009 and provided for rural office of tourist attractive villages of the region. Based on the extracted statistics, the number of all clients to the region was about 447,565 within the year 2009 (Table 1). Based on these statistics, it is assumed that $15,6,3,4$ and 2 percent of passengers who have visited the studied region for the purpose of business, pilgrim, visiting historical, natural and cultural \& art works, respectively in 2009 should select the location of the supposed hotel with annual average rate of 2.5 days for stay.

The number of resident passengers of hotel is equal to 19,918 in the first operation year (by assuming keeping the passengers fixed) and this number will reach to 24,249 with growth rate of $2 \%$ in twelfth operation year (Table 2).

Establishment of our desired hotel in centre of Rijab rural district in an area of about 2200 square meters would be made during 2 years. The 4 star hotel will have 46 rooms (22 Single, 18 Twin, 6 suites) in 6 stories and has facilities like permanent, seasonal restaurant and feast saloons and recreation and welfare facilities viz. pool, dry and steam sauna and Jacuzzi, body building and ping pong. In this plan, the space of -1 floor is marked for parking lot, kitchen, warehouse, service space and installments and floor will be used as lobby and restaurants and second floor as the pool and body building saloon and third to fifth floors as guest rooms and sixth floor as the feast saloon. All costs and incomes of 4 star hotel's plan has been estimated based on the existing principles and standards and raw data and information has been entered into Comfar software after compiling and computing and financial and economic indexes of the plan has been analyzed by using software output information. Meanwhile all output information of financial and economic indexes of Comfar software has been computed by using Excel software and the accuracy of information has been confirmed.

\section{Location and characteristics of the region}

Rijab rural district of Dalahou (Fig. 2 and 3) environs and with extent of 40 square kilometers is located in Western half of Kermanshah. This region has 15 villages and is located in latitude of 34 degrees and 26 minutes and longitude of 45 degrees and 55 minutes to 46 degrees and 5 minutes from Greenwich meridian. Geographical location of Rijab leads to Salas Babajani town from the North and to Dalahou town from the East and to Patagh rural district from the South and to Zahab desert and Iraq from the West. Based on the census of 2006, this rural district has 6700 populations which is the
Edu. Sust. Devpt.

CIndian Society for Education and Environment (iSee)
"Planning for rural tourism in Iran" http://www.indjst.org
A.Mahmoudi \& M.Mahdavi Indian J.Sci.Technol. 
Indian Journal of Science and Technology

Fig. 2. Location map of the region under consideration in range of Iran and Kermanshah Province

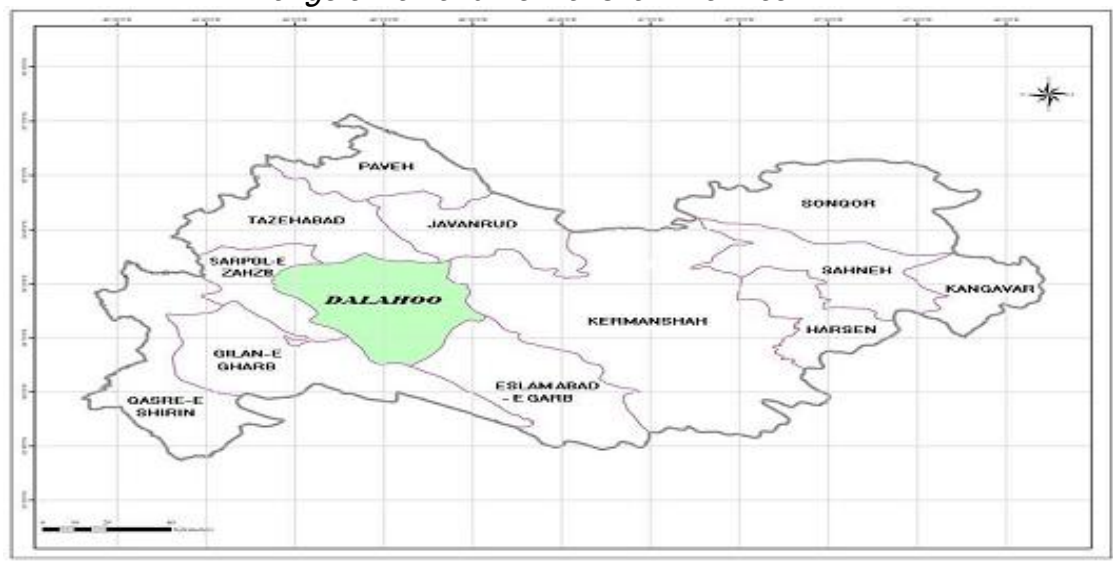

Vol. 4 No. 6 (June 2011)

ISSN: 0974- 6846

In terms of multitude of monuments and their diversity, it can be said that it's unique in this province and it's worthwhile that group of researchers and archeologists scientifically research and explore for days and months around that region (Golzari, 1978). Locating Rijab in margin of Shahi road (this road has connected the capitals of ancient Iran, Tisfoun - Bable to Shoush and Takht-E Jamshid) and Patagh gate (western gate of Iran plateau) increases the desired and appropriate natural location which has multiplied its strategic importance (tourism comprehensive plan of Rijab region, 2003). As it's clear from the ancient history,
Fig. 3. Map of Dalahou and situation of Rijab rural district in map of this town

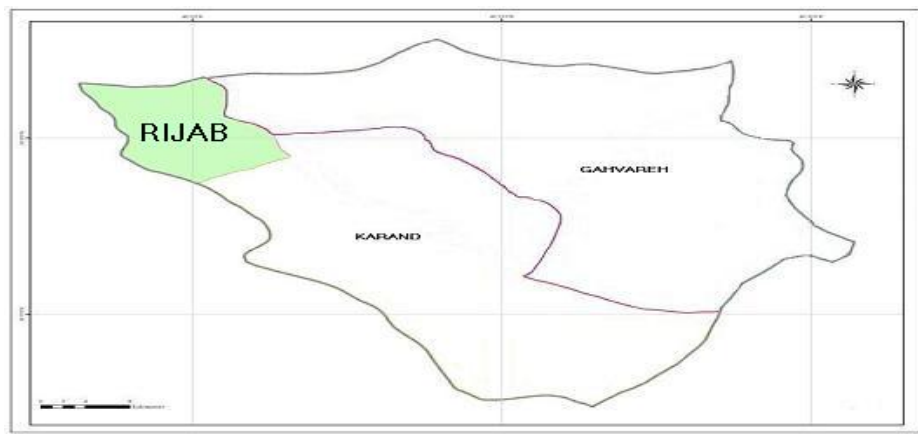

greatest village in terms of population of Banmazaran village (Mahmoudi, 2006).

Kermanshah by having climatic diversity, snowy mountains and summits, caves, waterlogged rivers and beautiful mirages has always been considered by tourists. More than half of the extent of province has been covered by high mountains. This province by having more than 600 monuments is one of the most spectacular regions of Iran. Dispersion of monuments and natural beautiful attractions is in such a manner that averagely there is a monument or paradise in each 15 to 20 kilometer. The existence of remains of living in cave era and then civilizations like Elamite, Lului, Sumerian and remains of local government or hierarchy of kings like Media, Achaemenian, the Parthia, Sassanid, Mongol, Tribalism, Safavid and Qajar dynasty in Kermanshah has distinguished old history of this region. (Geography book of Kermanshah, 2006).

Rijab region is unique in terms of natural conditions and environmental factors (Peroni, 2008), non uniformity, diverse natural features like mountains, valleys, rivers, waterways, medical, decorative herbs and gardens. The highest point of Rijab is 2540 meters and the lowest point is 500 meters from sea level. $46 \%$ of its area is located between heights of 520 to 1100 meters and $54 \%$ between 1100 to 2540 meters (Afshar Sistani, 1992).
Sassanid kings have been spending some times in Rijab in their royalty and political traveling between capitals (political transportation) and totally, all ancient works and buildings in Rijab indicate its residential and historical antiquity from the ancient periods up to now (Zendeh del, 2000).

\section{Plan of income}

The first step in analyzing economical feasibility of conducting any economic activity is the determination of its profitability. Accordingly, incomes and costs of plan and then justifiability of the plan will be firstly analyzed. In general, the main incomes which will be predicted to be obtained after performing plan considering kind and specifications of desired plans are:

The obtained income from selling room: Prediction of these incomes considering number and combination of rooms and percentage of estimated occupation in Table 2 and fixing the prices will be made. The first required index for computing income after index of percentage of occupation is price index. Therefore, rent of each room with separation of type of room will be firstly determined and then average weight of price of each room will be computed according to Table 3 . The obtained income from rent of stay of passengers in 2013 (1st operation year):

Number of room (46) $\times$ percentage of occupation (69.78\%) $x$ average weight of price of each room for each passenger $(1,483,074) \times 365=17,375$ Million Rials.

For estimating income of future years of plan, considering increase procedure of percentage of occupation and fixing rent rate of room based on fixed prices of year of 2013, some computations have been

Table 3. Cost of stay services of 4 star hotel of Rijab

\begin{tabular}{|c|c|c|c|c|}
\hline $\begin{array}{c}\text { Type of } \\
\text { room }\end{array}$ & $\begin{array}{c}\text { Number } \\
\text { of rooms }\end{array}$ & $\begin{array}{c}\text { Proportional } \\
\text { ratio }\end{array}$ & $\begin{array}{c}\text { Rate of } \\
\text { room (Rial) }\end{array}$ & $\begin{array}{c}\text { Average } \\
\text { weight } \\
\text { (Rial) }\end{array}$ \\
\hline Single Room & 22 & $47.74 \%$ & $1,110,000$ & 529,914 \\
\hline Twin Room & 18 & $39.26 \%$ & $1,600,000$ & 628,160 \\
\hline Suite & 6 & $13.00 \%$ & $2,500,000$ & 325,000 \\
\hline Total & 46 & $100 \%$ & - & $1,483,074$ \\
\hline \multicolumn{4}{rl}{ made (Table 5) }
\end{tabular}

Edu. Sust. Devpt.

CIndian Society for Education and Environment (iSee)
"Planning for rural tourism in Iran" http://www.indjst.org
A.Mahmoudi \& M.Mahdavi Indian J.Sci.Technol. 
Table 4. Estimate of number of ceremonies held during operation period of plan

\begin{tabular}{|c|c|c|c|c|c|c|c|c|c|c|c|c|}
\hline Year & 2013 & 2014 & 2015 & 2016 & 2017 & 2018 & 2019 & 2020 & 2021 & 2022 & 2023 & 2024 \\
\hline $\begin{array}{c}\text { Number of } \\
\text { ceremonies }\end{array}$ & 150 & 155 & 160 & 165 & 170 & 170 & 170 & 170 & 170 & 170 & 170 & 170 \\
\hline
\end{tabular}

obtained income from laundry and ... amount of $6 \%$ of total incomes of

Table 5. Incomes of 4star hotel's plan of Rijab during operation (Million Rials)

\begin{tabular}{|l|c|c|c|c|c|c|c|c|c|c|c|c|}
\hline $\begin{array}{c}\text { Year } \\
\text { Description }\end{array}$ & 2013 & 2014 & 2015 & 2016 & 2017 & 2018 & 2019 & 2020 & 2021 & 2022 & 2023 & 2024 \\
\hline Room Income & 17,375 & 17,787 & 18,231 & 18,578 & 19,141 & 19,644 & 20,207 & 20,413 & 20,586 & 20,979 & 21,122 & 21,154 \\
\hline Income of food, saloon & 10,800 & 11,160 & 11,520 & 11,880 & 12,240 & 12,240 & 12,240 & 12,240 & 12,240 & 12,240 & 12,240 & 12,240 \\
\hline $\begin{array}{l}\text { Income of food, beverage } \\
\text { in permanent restaurant }\end{array}$ & 3,332 & 3,379 & 3,430 & 3,470 & 3,534 & 3,592 & 3,656 & 3,680 & 3,700 & 3,745 & 3,761 & 3,765 \\
\hline $\begin{array}{l}\text { Income of food, beverage } \\
\text { in seasonal restaurant }\end{array}$ & 1,340 & 1,340 & 1,340 & 1,340 & 1,340 & 1,340 & 1,340 & 1,340 & 1,340 & 1,340 & 1,340 & 1,340 \\
\hline Coffee shop income & 348 & 350 & 352 & 353 & 356 & 358 & 361 & 362 & 362 & 364 & 365 & 365 \\
\hline Income of parking rent & 515 & 515 & 515 & 515 & 515 & 515 & 515 & 515 & 515 & 515 & 515 & 515 \\
\hline Incomes on side & 1,043 & 1,067 & 1,094 & 1,115 & 1,148 & 1,179 & 1,212 & 1,225 & 1,235 & 1,259 & 1,267 & 1,269 \\
\hline Total income & 34,753 & 35,598 & 36,481 & 37,250 & 38,274 & 38,867 & 39,531 & 39,774 & 39,978 & 40,441 & 40,610 & 40,648 \\
\hline
\end{tabular}

The obtained income from selling food, beverage, saloon and ceremony. with regard to considering the average operative capacity of saloon for 400 persons and prediction of number of ceremony in each year with estimate of menu rate has been computed 180,000 Rials. Also, for future years by using estimate of number of ceremony and keeping the prices fixed and operative capacity of saloon, the obtained income from selling food and beverage will be predicted and reflected in Table 4 .

The obtained income from selling food and beverage in permanent restaurant. Considering the studied conclusions and estimate of number of passengers for one night stay in hotel, one meal and using entertainment services with rate of 100,000 Rials and also 40 guests out of hotel has been considered for 335 days (except Ramezan month). Accordingly, the predicted income in first operation year of this place is equal to:

\{Number of serving of each meal (equal to

passengers) + number of guests in 335 days except passengers of hotel $\} \times$ rate of each serving $=(19,918+$ $13,400) \times 100,000=3,332$ Million Rials

Accordingly, the aforementioned income has been predicted for future years in Table 5.

The obtained income from selling food and beverage of seasonal restaurant of guests. This part of restaurant has been into consideration in a developed space for daily services and entertainment of 40 guests for 335 working days with menu rate of 100,000 Rials.

Coffee shop income: the obtained income from coffee shop sale by considering usage of $10 \%$ of passengers of hotel during one year and recreational services of coffee shop for 20 non-resident guests for 335 working days has been estimated with menu rate of 40,000 Rials in Table 5 . The obtained income from parking rent. Considering 365 working days with rate of 15,000 Rials and using 47 places 2 times a day which have been devised for parking, the income will be gained.

Income on side: Sum of income on side includes the obtained income from being operator in conversations, rooms have been estimated (Table 5) during 2013- 2024.

Plan of costs

The second action in establishing a new hotel is its financial predictions. Considering the predicted

Table 6. Estimate of project investment with separation of construction period (Million Rials)

\begin{tabular}{|c|c|c|c|}
\hline description & $\begin{array}{c}\text { Total } \\
\text { construction } \\
\text { phase }\end{array}$ & $\begin{array}{c}2011 \\
\text { Year }\end{array}$ & $\begin{array}{c}2012 \\
\text { Year }\end{array}$ \\
\hline precinct and land improvement & 50,000 & 22,850 & 27,150 \\
\hline municipality charges & 7,000 & 2,800 & 4,200 \\
\hline machineries and facilities & 14,250 & 5,700 & 8,550 \\
\hline side and service facilities & 23,750 & 9,500 & 14,250 \\
\hline total fixed costs of investment & 95,000 & 40,850 & 54,150 \\
\hline
\end{tabular}

specifications for establishing the aforementioned hotel and considering all installment and equipment requirements which is necessary that this plan could be utilized considering the degree of hotel, estimate of cost is separately mentioned for each life years of the plan.

Plan investment fixed cost. It is assumed that in the fixed costs of plan's investment, the land will be freely given to the investor. The estimated amount for fixed investment of plan is 95,000 Million Rials which an amount of 40,850 Million Rials for the first year and 54,150 Million Rials have been estimated considering 2 years construction phases which its complete description is in Table 6. Also, 16 operational personnel are predicted in hotel with 82.5 Million Rials per capita as the personnel cost and amount of 833 Million Rials has been considered as the working capital.

Cost estimate of annual insurance: Insurances which have been now considered to be standard for hotels and common in Iran are:

Fire, lightning and explosion insurance: the basis of computing this kind of insurance based on the existing tariff is $0.00305 \%$ of all primary investment minus cost of buying land and municipality dues which have been computed as follows: $(95,000-5,273) \times 0.003 \%=269$ Million Rials 
Table 7. Operation costs of plan (Million Rials)

\begin{tabular}{|c|c|c|c|c|c|c|c|c|c|c|c|c|}
\hline Year & 2013 & 2014 & 2015 & 2016 & 2017 & 2018 & 2019 & 2020 & 2021 & 2022 & 2023 & 2024 \\
\hline Description & 2013 & 2014 & $\angle 015$ & 2010 & 2017 & $\angle 018$ & $\angle 019$ & $\angle O \angle O$ & $\angle O Z 1$ & $\angle O Z Z$ & $\angle 0 \angle 3$ & $\angle 0 \angle 4$ \\
\hline Salary and Wage & 1,320 & 1,320 & 1,320 & 1,320 & 1,320 & 1,320 & 1,320 & 1,320 & 1,320 & 1,320 & 1,320 & 1,320 \\
\hline Insurance & 270 & 270 & 270 & 270 & 270 & 270 & 270 & 270 & 270 & 270 & 270 & 270 \\
\hline Energy & 463 & 470 & 471 & 471 & 474 & 472 & 474 & 472 & 472 & 474 & 473 & 472 \\
\hline Telecommunication & 174 & 178 & 182 & 186 & 191 & 194 & 198 & 199 & 200 & 202 & 203 & 203 \\
\hline $\begin{array}{l}\text { Food and } \\
\text { beverage cost }\end{array}$ & 5,062 & 5,193 & 5,325 & 5,454 & 5,590 & 5,610 & 5,631 & 5,639 & 5,645 & 5,660 & 5,666 & 5,667 \\
\hline $\begin{array}{l}\text { Consuming } \\
\text { supplies }\end{array}$ & 455 & 466 & 478 & 488 & 501 & 509 & 518 & 521 & 524 & 530 & 532 & 532 \\
\hline $\begin{array}{l}\text { Repair and } \\
\text { maintenance }\end{array}$ & 180 & 203 & 213 & 226 & 243 & 262 & 284 & 302 & 323 & 347 & 365 & 385 \\
\hline Advertising & 695 & 712 & 730 & 745 & 765 & 777 & 791 & 795 & 800 & 809 & 812 & 813 \\
\hline Depreciation & 10,403 & 9,589 & 8,875 & 8,247 & 7,694 & 4,356 & 3,925 & 3,543 & 3,203 & 2,902 & 2,632 & 2,392 \\
\hline Financial costs & 5,594 & 5,594 & 5,594 & 5,594 & 5,594 & 0 & 0 & 0 & 0 & 0 & 0 & 0 \\
\hline Other costs & 711 & 720 & 729 & 738 & 747 & 471 & 474 & 476 & 478 & 481 & 482 & 483 \\
\hline Total & 25,327 & 24,715 & 24,187 & 23,739 & 23,389 & 14,241 & 13,885 & 13,537 & 13,235 & 12,995 & 12,755 & 12,537 \\
\hline
\end{tabular}

Group life insurance: share of hotel for paying life insurance of personnel is 70,000 Rials in lieu of each person per year. Accordingly, group life insurance cost of personnel is: $70,000 \times 16=1$ Million Rials

Sum of annual insurance is equal to 270 Million Rials. Energy cost estimate: Estimate of different costs of energy including electric energy cost, consuming water and fuel according to the necessary standards of plan has been predicted and inserted in Table 7.

Cost estimate of consuming raw material of restaurant. Raw material of restaurant includes consuming material for preparing breakfast, lunch and dinner which the cost of this material has been averagely considered equal to $32 \%$ of obtained income from selling food and beverage. Accordingly, the cost of raw material has been computed and inserted in Table 7 for all years of plan.

Cost estimate of consuming requirements: Cost estimate of consuming requirements has been made for the desired plan by studying the existing norm and doing adjustments proportionate to the percentage of predicted occupation of plan. These costs include cost of consuming requirements in the room, hygienic material, dishes and chinaware and sundry items which its results will be seen in Table 7.

Estimate of repairs and maintenance cost. For the purpose of keeping the building, installments, equipments and transportation vehicles, some annual costs according to the standard norms and under title of repair and maintenance cost has been predicted with logical growth rate for future years in Table 7.

Estimate of conversations' cost: The estimate of this cost has been made on the basis of $1 \%$ of total income of hotel's rooms.

Estimate of advertising cost. Considering the existing standards, residential places like economic institutions shall annually spend 1 to 3 percents of their total income for marketing matters for developing range of their own target market. Therefore, considering this issue and also performed studies regarding corresponding hotels, we considered 2 percents of total income of hotel for this purpose.

Estimate of amortization cost. Regarding estimate of this cost considering the amortization Tables, amortization rate for building, electrical installments, mechanical installments and equipment has been computed descending 7 percents, 15 percents, 15 percents and direct 5 year amortization respectively through Comfar software considering the separation of plan investment and total operation costs have been presented in Table 7 . Estimate of financial cost. Financial resources of plan includes $40 \%$ cash share and $60 \%$ remaining through bank facilities with 5 year payback period will be funded with rate of $11 \%$ which all financial costs of plan have been presented in Table 7. Also rate of income tax is $12.5 \%$.

Unpredicted costs. After identifying cost items and their estimates for ensuring that all costs are considered, $4.76 \%$ of total estimated costs have been considered as unpredicted costs of plan which are inserted in Table 7.

\section{Economic and financial indexes of plan}

To make economic and financial assessment of plan, a series of indexes will be reviewed. Comfar and Excel software has been used for computing these indexes. The most important required indexes, computation manner and their general concepts are mentioned in economic and financial analysis of plan.

Net present value (NPV)

Net present value indicates difference of present value of all plan incomes (obtained from selling product or service) and costs of plan (all consumed resources) of its computation manner is described as follows:

If amount of $A$ Rial with rate of $i$ percents will be $P$ Rial for $n$ years:

$P=A(1+i)^{n}$

In this case, present value of $P$ Rial will be obtained after $\mathrm{n}$ years:

$A=\frac{P}{(1+i)^{n}}$
Edu. Sust. Devpt.

CIndian Society for Education and Environment (iSee)
"Planning for rural tourism in Iran" http://www.indjst.org
A.Mahmoudi \& M.Mahdavi Indian J.Sci.Technol. 
Table 8. Summary of Comfar computations' results of

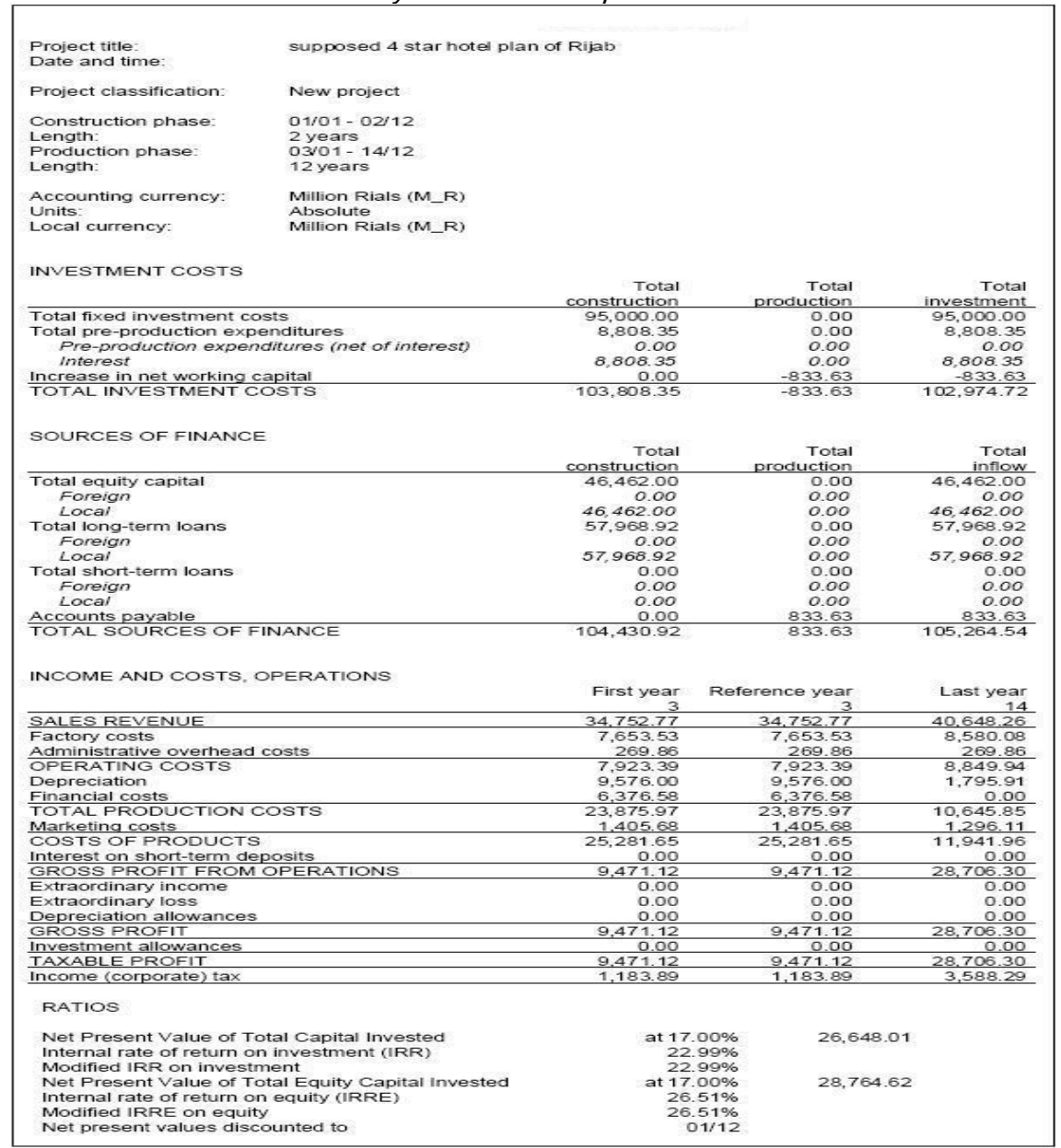

$i$ is the discount rate. If $i=0$, then $\mathrm{P}=\mathrm{A}$ and there's no difference between present and future value. If inflow and outflow in successive years is $E j$ and $R j$ for $n$ years, net present value of incomes is:

$N P V=($ R. $-E$. $)+\frac{\mathrm{R}_{1-} \mathrm{E}_{1}}{(1+\mathrm{i})^{1}}+\frac{\mathrm{R}_{2}-\mathrm{E}_{2}}{(1+\mathrm{i})^{2}}+\frac{\mathrm{R}_{3}-\mathrm{E}_{3}}{(1+\mathrm{i})^{3}}+\cdots \frac{\mathrm{R}_{\mathrm{n}-} \mathrm{E}_{\mathrm{n}}}{(1+\mathrm{i})^{\mathrm{n}}}=\sum_{\mathrm{j}=0}^{\mathrm{n}} \frac{\mathrm{R}_{\mathrm{j}-\mathrm{E}_{\mathrm{j}}}}{(1+\mathrm{i})^{\mathrm{j}}}$

We've computed computations related to the net present value considering its formula which its result is identical with computations of Excel software which automatically compute this task.

$N P V=(-40.850)+\frac{-54.150}{(1+17 \%)^{1}}+\frac{25.006}{(1+17 \%)^{2}}+\frac{24.586}{(1+17 \%)^{3}}+\cdots \frac{26.919}{(1+17 \%)^{12}}+\cdots \frac{69.770}{(1+17 \%)^{13}}=26.648$

Net present value in 4 star hotel plan with primary investment is 95,000 Million Rials and net cash flow of the first year is $-40,850$ Million Rials which will be reached to 69,770 Million Rials in the last operation year (scrap value is added to the net cash flow of the last operation year) and by assuming $17 \%$ discount rate and 12 year life of plan is equal to 26,648 Million Rials which non negative net present value in $17 \%$ discount rate indicates the plan is economical (Table 8).

Net present value of equity capital (NPVE): This indicates difference of present value of equity capital incomes (received share profit) and equity capital costs (cash). Non negative net present value in discount rate equal to
Vol. 4 No. 6 (June 2011)

ISSN: 0974- 6846

the opportunity cost of investor indicates that the project is economical from the investor's point of view. Net present value of total capital of 4 star hotel's plan is positive and a figure equal to 28,765 Million Rials (Table 8).

Internal rate of return (IRR): The internal rate of return is a rate which allocated resources to the plan will make profit with that rate and is more used for analyzing economy of executive engineering (Akbari, 2003). For computing internal rate of return, net present value will be equal to 0 $(\mathrm{NPV}=0)$ and internal rate of return more than discount rate (opportunity cost of capital) indicate the plan is economical. In this relation:

$\mathbf{I R R}=-\mathrm{I}+\frac{\mathrm{R}}{(1+\mathrm{i})^{1}}+\frac{\mathrm{R}}{(1+\mathrm{i})^{2}}+\frac{\mathrm{R}}{(1+\mathrm{i})^{3}}+\cdots+\frac{\mathrm{R}}{(1+\mathrm{i})^{\mathrm{n}}}$

Whatever the discount rate $i$ is more, net present value of incomes are less and we see that net present value of incomes is equal to zero in lieu of $i=\bar{i}$ This $i$ quantity is called internal profitability coefficient or internal rate of return of plan. Economic concept (IRR) is maximum interest or profit which the investor can pay for financing the plan because if he pays more, NPV will be negative and it causes loss. Internal rate of return of 4 star hotel's plan in Rijab is $22.99 \%$ (Fig. 4 and Table 8).

Internal rate of return on equity (IRRE): It indicates return of equity allocated to the plan through investors. From investor point of view, the received share profit will be considered as the benefits of investor and allocated equity to the plan as the investment cost. Internal rate of return on equity more than discount rate (opportunity cost of investor) indicates the plan is economical from the investor point of view. Internal rate of return of rights of share owners of 4 star hotel's plan is $26.51 \%$ (Table 8).

Normal payback period: It is the period which total performed investments will be returned by obtained incomes from the plan (without regard to their time value). In other words, capital payback period is one in which costs of plan is reimbursed with its net incomes which the capital will be amortized. For example, normal payback period with 100 Million Rial investment with annual net income of 20 Million Rial is 5 years. In this method, more payback period, better investment.

The advantage of this method is its simplicity and easiness for considering investment risk factor. For accepting or rejecting the plan, there's maximum $T$ period. For example, farmers may only accept plans which their payback period is less than 5 years. In former 
Fig. 4. Discounted cash flows by using Comfar Software

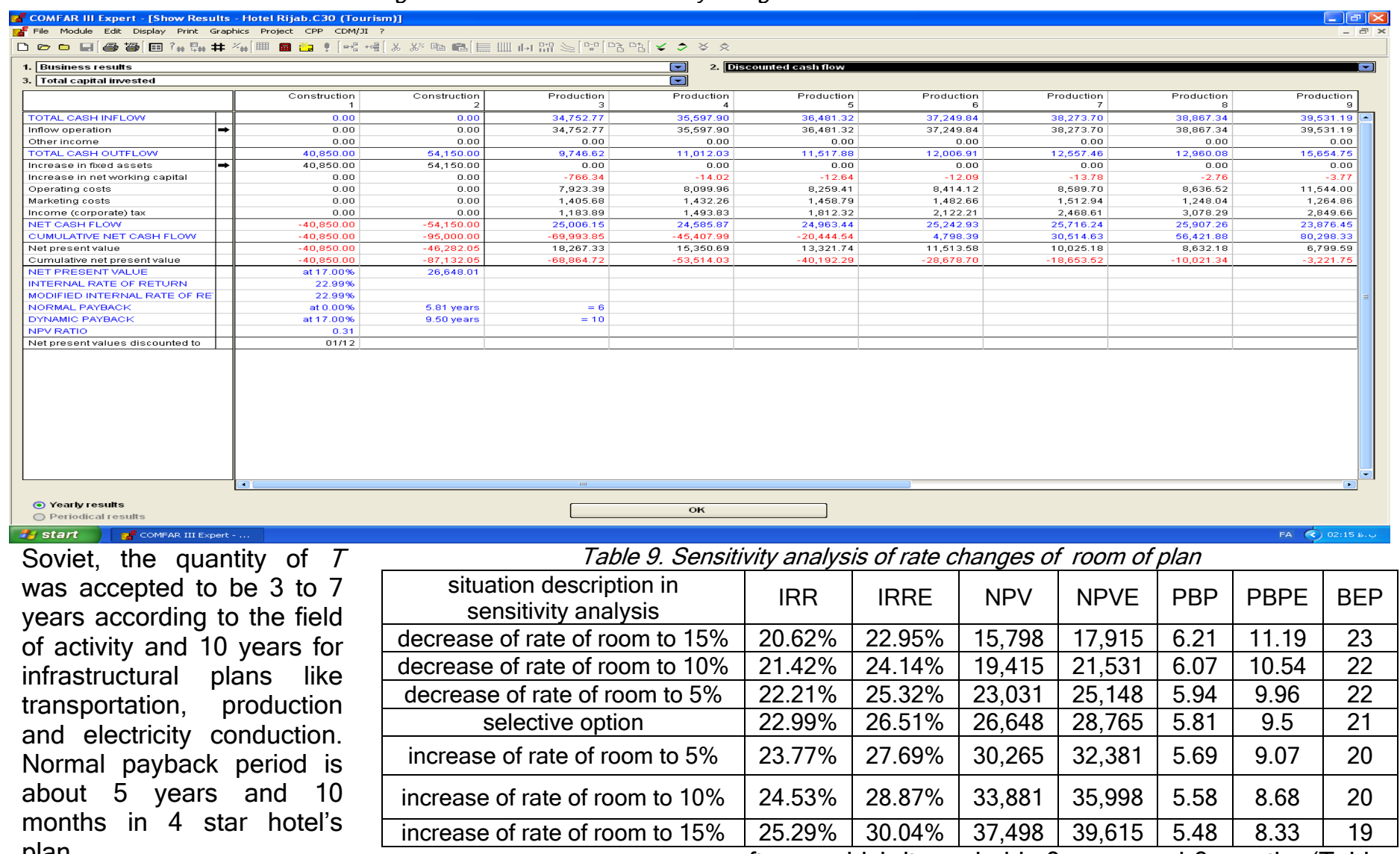

plan.

Dynamic payback period. It is the period which total performed investments will be returned by obtained incomes from the plan (with regard to their time value). Defect of normal payback period is that it doesn't consider time factor. For resolving this defect, it's enough that net present value of incomes will be involved in computing payback period. By assuming that net income is fixed for $j=1, \cdots, \mathrm{t}$ :

$-\mathrm{I}+\sum_{\mathrm{i}=1}^{\mathrm{t}} \frac{\mathrm{R}}{(1+\mathrm{i})^{\mathrm{j}}}=-\mathrm{I}+\frac{\mathrm{R}}{\mathrm{i}}\left[1-\left(\frac{1}{1+\mathrm{i}}\right)^{\mathrm{t}}\right]$

$-\mathrm{I}+\frac{\mathrm{R}}{\mathrm{i}}-\frac{\mathrm{R}}{\mathrm{i}}\left(\frac{1}{1+\mathrm{i}}\right)^{\mathrm{t}}=$.

$-I+\frac{R}{i}=\frac{R}{i}\left(\frac{1}{1+i}\right)^{t}$

$-\mathrm{I}+\sum_{\mathrm{j}=1}^{\mathrm{t}} \frac{\mathrm{R}}{(1+\mathrm{i})^{\mathrm{j}}}=-\mathrm{I}+\frac{\mathrm{R}}{\mathrm{i}}\left[1-\left(\frac{1}{1+\mathrm{i}}\right)^{\mathrm{t}}\right]$

$-\mathrm{I}+\frac{\mathrm{R}}{\mathrm{i}}-\frac{\mathrm{R}}{\mathrm{i}}\left(\frac{1}{1+\mathrm{i}}\right)^{\mathrm{t}}=$.

By dividing both sides of the above equation:

$1-\frac{\mathrm{Ii}}{\mathrm{R}}=\left(\frac{1}{1+\mathrm{i}}\right)^{\mathrm{t}}$

And by considering that: $\log \left(1-\frac{\mathrm{Ii}}{\mathrm{R}}\right)=\operatorname{tog}\left(\frac{1}{1+\mathrm{i}}\right)$

$\mathrm{t}=\frac{\log \left(1-\frac{\mathrm{Ii}}{\mathrm{R}}\right)}{\log \left(\frac{1}{1+\mathrm{i}}\right)}$

Dynamic payback period of plan is computed regarding the aforesaid formula and by using Comfar and Excel software which its period is 9 years and 6 months (Table 8).

Breakeven analysis: It is determiner of capacity of production in which sale income covers production costs. Production more than breakeven indicates locating in profit situation and less production being in loss situation.

High breakeven indicates high risk of plan against unpredicted factors (Mostazafan Foundation of Islamic Revolution, 2007). Breakeven of this plan will be obtained by selling 21 rooms of total rooms.

Sensitivity analysis: It is a method for reviewing and evaluating approval of key parameters on financial indexes of plan and reviews risk of performing plan in different states (consulting engineers of Nazm Pouyan management, 2006) and somehow is kind of review toward economic evaluation. This question can be asked that the primary estimates can well indicate conditions which will be occurred in the future after performing project (Oskoonezhad, 2006). Key and affecting variables on rate of profitability of this plan are: changes in rate of room, percentage of occupation which rate of analysis of economic and financial indexes are shown by increasing and decreasing these variables in Tables 9 and 10 .

\section{Conclusion}

One way of gaining national income and importing foreign currency is to create residential and recreational facilities beside tourism center and attractions. Therefore, creating suitable facilities for domestic and foreign tourists can have a significant
Edu. Sust. Devpt.

CIndian Society for Education and Environment (iSee)
"Planning for rural tourism in Iran" http://www.indjst.org
A.Mahmoudi \& M.Mahdavi Indian J.Sci.Technol. 
Table 10. Sensitivity analysis of changes of average percent of occupation

\begin{tabular}{|c|c|c|c|c|c|c|c|}
\hline $\begin{array}{c}\text { situation description in } \\
\text { sensitivity analysis }\end{array}$ & IRR & IRRE & NPV & NPVE & PBP & PBPE & BEP \\
\hline $\begin{array}{c}\text { decrease of percentage } \\
\text { of occupation to 15\% }\end{array}$ & $20.64 \%$ & $22.98 \%$ & 15,905 & 18,021 & 6.21 & 11.17 & 22 \\
\hline $\begin{array}{c}\text { decrease of percentage } \\
\text { of occupation to 10\% }\end{array}$ & $21.50 \%$ & $24.26 \%$ & 19,723 & 21,840 & 6.05 & 10.48 & 22 \\
\hline $\begin{array}{c}\text { decrease of percentage } \\
\text { of occupation to 5\% }\end{array}$ & $22.90 \%$ & $26.36 \%$ & 26,292 & 28,409 & 5.83 & 9.55 & 21 \\
\hline $\begin{array}{c}\text { selective option } \\
\text { increase of percentage } \\
\text { of occupation to 5\% }\end{array}$ & $22.99 \%$ & $26.51 \%$ & 26,648 & 28,765 & 5.81 & 9.5 & 21 \\
\hline $\begin{array}{c}\text { increase of percentage } \\
\text { of occupation to 10\% }\end{array}$ & $24.52 \%$ & $28.68 \%$ & 30,229 & 32,346 & 5.69 & 9.07 & 21 \\
\hline $\begin{array}{c}\text { increase of percentage } \\
\text { of occupation to 15\% }\end{array}$ & $25.27 \%$ & $30.01 \%$ & 37,391 & 39,508 & 5.48 & 8.34 & 20 \\
\hline
\end{tabular}

ISSN: 0974- 6846

specially, decrease changes don't negatively affect on performing plan and it has economic justification.

All economic and financial indexes of plan indicate justifiability of plan of establishing 4 star hotel in the region under consideration. It will also promote subsequent employment opportunities, income, cultural exchanges, preserving cultural values, agricultural development and morale reinforcement of innovation and handicraft produce. Such developments can also mitigate many problems especially rural area which mainly encounter with risk of immigration, evacuation and stagnation and unemployment. Hospitality industry can nourish the human talents and rural skill to put it natural and practical.

For future development the following are suggested: 1) Use

role in the country's economic progress. Our ancients have presented valuable heritage for us. Capital which has antiquity up to Iranian history and is easily available for us as a valuable basis for investing in hospitality industry. In this research, we able to identify and estimate primary investment and total operation costs and predict incomes of this plan and also did computations by using Comfar and Excel software, results of following economic indexes have been obtained in order to establish 4 star hotel in Rijab region:

- In computing net present value of plan (NPV) by assuming $17 \%$ discount rate, three states will be occurred. In the first state $(\mathrm{NPV})<0$, it means that present value of costs is more than present value of incomes and in other words, net present value of plan is negative and project is non economical. In the second state (NPV) $>0$, it means that present value of costs is less than present value of incomes and the project is economical and in the third state $(\mathrm{NPV})=0$, it means that minimum attracting rate is provided for investment and consequently, the project is economical. In economic comparison of some projects by present value, the project is the most economical one which has more net present value. In the present plan, the second state has been occurred and net present value of total plan and share of investor is 26,648 and 28,765 Million Rials, respectively.

- During operation period, internal rate of return of plan (IRR) and internal rate of return on equity is $22.99 \%$ and $26.51 \%$, respectively. Thus, the plan has economic justification as both rates are great in comparison with rate of bank interest (11\%).

- Payback period of plan is an approximate method for economic comparison of projects. The analyzer is seeking for a period which primary capital can be reimbursed by annual incomes by using this method. Normal and dynamic payback period of plan is about 6 and 10 years during operation period, respectively.

- Break even review of cost and income of plan indicates that by averagely selling 21 out of 46 rooms or in other words, selling $45 \%$ of rooms, the plan will be reached to covering point of costs without margin of positive profit which indicates justifiability of plan.

- The performed sensitivity analysis in two affecting parameters in hospitability includes variable of average percent of hotel's occupation and average of sales price of a room by considering increase and decrease changes in 5, 10 and $15 \%$ rates and its effect on economic evaluation indexes indicate that net present value of plan (NPV) is positive and internal rate of return more than discount rate $(17 \%)$ has been considered which performed computations and fluctuations Edu. Sust. Devpt.

CIndian Society for Education and Environment (iSee)

"Planning for rural tourism in Iran" http://www.indjst.org of this model for financial and economical evaluation of other service projects such as construction of telecab, park and game centre, cinema, Sleigh, and construction projects. 2) With suitable modifications, this model can be employed in all activities related to planning, execution, and termination of projects.

\section{Acknowledgements}

I thank Mr. Mohammad Forouzandeh, respective Director of Mostazafan Foundation of Islamic Revolution,Mr. Mehdi Tafazzoli (Deputy Development and Technology) and Mr.Ahmad Salavati (Technology manager) for holding educational course of Comfar Software and my participation in these courses.

\section{References}

1. Afshar Sistani I (1992) Kermanshahan and its ancient civilization. Zarrin Publ., Iran (In Persian). pp:150.

2. Akbari $H$ (2003) Economy of engineering, concepts and techniques of economy of engineering. Tose-E Ghalam Publ., Iran (In Persian). pp:141.

3. Consulting Engineers of Nazm Pouyan Management (2006) Instruction of financial data collection of Comfar software, Iran (In Persian). pp:119.

4. Geography Book of Kermanshah (2006) Publication of Iran Textbooks. Iran (In Persian). pp: 65-68.

5. Golzari M (1978) Ancient Kermanshahan (from the beginning until end of 13th Hejira century). Farhang \& Honar Publ.

6. Mahmoudi AR (2006) The tourism landscape of Rijab area. Taghe Bostan Publ., Iran (In Persian). pp:35.

7. Mostazafan Foundation of Islamic Revolution, Development and Technology Deputy (2007) Practical guide in preparation of justificatory report of plan from market, technical, financial and economic dimensions. Iran (In Persian). pp: 61.

8. Oskoonezhad MM (2006) Engineering economy or economic evaluation of industrial projects. Amirkabir Publ., Iran (In Persian). pp:28.

9. Peroni J (2008) Marketing of tourism. Khajeh Publ. p: 2.

10. Tourism comprehensive plan of Rijab area (2003) Handicrafts and tourism of Kermanshah. Cultural Heritage Organization, Iran (In Persian). pp:179.

11. United Nations Industrial Development Organization (2008) Reference guide of specialized 3 Comfar software (specialized software of financial and economic evaluation of plans), Nazm Pouan Sanat Novin Publ. p:11.

12. Zendeh Del H (2000) Set of Iranian tourism comprehensive guide of Kermanshah. Iran Garden publ., Iran (In Persian). pp:101. 